Original article

\title{
HPLC analysis and standardization of Brahmi vati - An Ayurvedic poly-herbal formulation
}

\author{
Amrita Mishra ${ }^{a, b}, *$, Arun K. Mishra a , Om Prakash Tiwari a , Shivesh Jha ${ }^{b}$ \\ a Department of Pharmacognosy, School of Pharmaceutical Sciences, IFTM University, Moradabad 244001, India \\ ${ }^{\mathrm{b}}$ Department of Pharmaceutical Sciences, Birla Institute of Technology, Ranchi 835215, India
}

\section{A R T I C L E I N F O}

\section{Article history:}

Received 6 June 2013

Accepted 5 September 2013

Available online 30 September 2013

\section{Keywords:}

Brahmi vati

Bacoside $\mathrm{A}_{3}$

Piperine

HPLC

\begin{abstract}
A B S T R A C T
Objectives: The aim of the present study was to standardize Brahmi vati (BV) by simultaneous quantitative estimation of Bacoside $\mathrm{A}_{3}$ and Piperine adopting HPLC-UV method. BV very important Ayurvedic polyherbo formulation used to treat epilepsy and mental disorders containing thirty eight ingredients including Bacopa monnieri L. and Piper longum L.

Materials and methods: An HPLC-UV method was developed for the standardization of BV in light of simultaneous quantitative estimation of Bacoside $\mathrm{A}_{3}$ and Piperine, the major constituents of $B$. monnieri L. and $P$. longum L. respectively. The developed method was validated on parameters including linearity, precision, accuracy and robustness.

Results: The HPLC analysis showed significant increase in amount of Bacoside $\mathrm{A}_{3}$ and Piperine in the inhouse sample of BV when compared with all three different marketed samples of the same. Results showed variations in the amount of Bacoside $\mathrm{A}_{3}$ and Piperine in different samples which indicate nonuniformity in their quality which will lead to difference in their therapeutic effects.

Conclusion: The outcome of the present investigation underlines the importance of standardization of Ayurvedic formulations. The developed method may be further used to standardize other samples of BV or other formulations containing Bacoside $\mathrm{A}_{3}$ and Piperine.
\end{abstract}

Copyright (C) 2013, InPharm Association, Published by Reed Elsevier India Pvt. Ltd. All rights reserved.

\section{Introduction}

Ayurveda, the ancient system of plant based medicines is gaining recognition throughout the world and many herbal drugs are now clinically tested and accepted for manufacturing in present scenario. ${ }^{1,2}$ Ayurvedic formulations have been used to cure the diseases in both humans and animals for centuries in the Indian subcontinent. These formulations are prepared by particular traditional processing methods which involve the use of several herbs and minerals. The Ayurvedic formulations are available in different forms such as powder, decoction, fresh juice, vati, oil, clarified butter preparations and alcoholic preparation. ${ }^{3}$ As per Ayurvedic Formulary of India (AFI), Brahmi vati (BV) is comprised of Brahmi (Bacopa monnieri) and another thirty-seven herbal and animal ingredients along with nine bhasmas. BV is one of the most important formulations used to cure mental disorders, epilepsy as well as to improve the memory. This polyherbo-mineral formulation also has cardio-protective and antipyretic actions but still

\footnotetext{
* Corresponding author.

E-mail address: amrita_azam@rediffmail.com (A. Mishra).
}

scientific evidences are lacking. The ingredients involved in the preparation of $\mathrm{BV}$ are presented in Table $1 .{ }^{4}$ The whole herb of Brahmi (B. monnieri L.) is used for alleviating the mental and cardiovascular conditions since ancient time. In a recent study, the alcoholic extract of $B$. monnieri enhanced the learning ability in rats. ${ }^{5,6}$ Alcoholic extract of $B$. monnieri has shown cognition facilitating effect in normal rats and inhibited the amnesic effects of scopolamine and immobilization stress. ${ }^{7,8}$ In behavioral response studies, alcoholic extract of $B$. monnieri facilitated the cognitive function and augmented the mental retention capacity. ${ }^{9}$

The chief plant ingredient of BV, Brahmi (B. monnieri L., family Scrophulariaceae) is a native plant of India. The plant is reported to contain steroidal saponin, alkaloid and glycosides etc. ${ }^{10}$ Number of formulations containing Bacoside as active constituent has been already in market as memory plus, Brahmi Ghrita, Sarasvati ristha, Ratnagiri rasa and Smritisagar rasa. Piper longum fruits, another chief constituent of $\mathrm{BV}$, have alkaloids as the main constituent. ${ }^{11}$ Bacoside $A_{3}$ the main triterpenoid saponins now regarded as responsible for the characteristic neuropharmacological effects of the B. monnieri. ${ }^{12}$ Piperine, the main alkaloid of $P$. longum, protects against neurodegeneration and cognitive impairment in animal model of cognitive deficit like condition of Alzheimer's disease. ${ }^{13}$ 
Table 1

Ingredients of Brahmi vati formulation.

\begin{tabular}{|c|c|c|c|}
\hline Name & Botanical name/Source & Part used & Quantity \\
\hline Abhraka bhasma & Calcined Biotite mica & - & $6 \mathrm{~g}$ \\
\hline Sangeyasaba pisti & Processed Jadite & - & $6 \mathrm{~g}$ \\
\hline Akik bhasma & Calcined agate & - & $6 \mathrm{~g}$ \\
\hline Manikya pisti & Processed ruby & - & $6 \mathrm{~g}$ \\
\hline Chandrodaya & Calcined sulfur and mercury & - & $6 \mathrm{~g}$ \\
\hline Pravala bhasma & Calcined red coral & - & $6 \mathrm{~g}$ \\
\hline Kaharuba pisti & Processed amber & - & $6 \mathrm{~g}$ \\
\hline Svarna bhasma & Calcined gold foil & - & $6 \mathrm{~g}$ \\
\hline Mukta bhasma & Calcined pearl & - & $6 \mathrm{~g}$ \\
\hline Jayaphala & Myristica fragrans Houtt. & Seed & $4 \mathrm{~g}$ \\
\hline Lavanga & Eugenia caryophyllata Thunb. & Flower bud & $4 \mathrm{~g}$ \\
\hline Kustha & Saussurea lappa C.B. Clarke. & Root & $4 \mathrm{~g}$ \\
\hline Jatipatri & Myristica fragrans Houtt. & Aril/Mace & $4 \mathrm{~g}$ \\
\hline Krsnajiraka & Carum carvi Linn. & Fruit & $4 \mathrm{~g}$ \\
\hline Pippali & Piper longum Linn. & Fruit & $4 \mathrm{~g}$ \\
\hline Tvak & $\begin{array}{l}\text { Cinnamomum zeylanicum } \\
\text { Blume. }\end{array}$ & Stem bark & $4 \mathrm{~g}$ \\
\hline Anisuna & Pimpinella anisum Linn. & Fruit & $4 \mathrm{~g}$ \\
\hline Ashwagandha & Withania somnifera Dunal. & Root & $4 \mathrm{~g}$ \\
\hline Akarkara & Anacyclus pyrethrum DC. & Root & $4 \mathrm{~g}$ \\
\hline Dhanyaka & Coriandrum sativum Linn. & Fruit & $4 \mathrm{~g}$ \\
\hline Vansalochana & $\begin{array}{l}\text { Bambusa arundinacea Retz. } \\
\text { Willd. }\end{array}$ & $\begin{array}{l}\text { Silicious } \\
\text { concretion }\end{array}$ & $4 \mathrm{~g}$ \\
\hline Ela & Elettaria cardamomum Linn. & Seed & $4 \mathrm{~g}$ \\
\hline Sankhapuspi & Convolvulus pluricaulis Choisy. & Plant & $4 \mathrm{~g}$ \\
\hline Sveta Chandana & Santalum album Linn. & Heart wood & $4 \mathrm{~g}$ \\
\hline Surpha & Foeniculum vulgare Mill. & Fruit & $4 \mathrm{~g}$ \\
\hline Patra & $\begin{array}{l}\text { Cinnamomum tamala Buch. } \\
\text { Ham. }\end{array}$ & Leaf & $4 \mathrm{~g}$ \\
\hline Nagakesara & Mesua ferrea Linn. & Androcium & $4 \mathrm{~g}$ \\
\hline Rumimastagi & Pistacia lentiscus Linn. & Exudates & $4 \mathrm{~g}$ \\
\hline Pippalimula & Piper longum Linn. & Root & $4 \mathrm{~g}$ \\
\hline Chitraka & Plumbago zeylanica Linn. & Root & $4 \mathrm{~g}$ \\
\hline Kulinjana & Alpinia galanga Willd. & Rhizome & $4 \mathrm{~g}$ \\
\hline $\begin{array}{c}\text { Kasturi/Lata } \\
\text { kasturi }\end{array}$ & Hibiscus abelmoschus Linn. & Seed & $18 \mathrm{~g}$ \\
\hline Amber & Ambergris & $\begin{array}{l}\text { Substance } \\
\text { produced from } \\
\text { digestive system } \\
\text { of sperm whales }\end{array}$ & $18 \mathrm{~g}$ \\
\hline Brahmi & Bacopa monnieri Linn. & Plant & $18 \mathrm{~g}$ \\
\hline Nisotha & Operculina turpethum Linn. & Root & $18 \mathrm{~g}$ \\
\hline Aguru & Aquilaria agallocha Roxb. & Heart wood & $18 \mathrm{~g}$ \\
\hline Kumkuma & Crocus sativus Linn. & Stigma & $18 \mathrm{~g}$ \\
\hline Brahmi svarasa & Bacopa monnieri Linn. & Plant & Q.S. \\
\hline
\end{tabular}

The aim of the present study was to develop high performance liquid chromatography-ultra violet (HPLC-UV) method to separate and quantify the Bacoside $\mathrm{A}_{3}$ (the main constituent of Brahmi) and Piperine (main constituent of $P$. longum) from BV samples as a tool for standardization. The proposed method was validated as per guidelines of the International Conference on Harmonization (ICH) ${ }^{14-16}$ The structures of Bacoside $A_{3}$ and Piperine are presented in Fig. 1. The content of Bacoside $A_{3}$ in $B$. monnieri and Piperine in $P$. longum were also evaluated to get the individual percent yield so that expected yield in the formulation can also be calculated.

The fingerprint analysis by HPLC/HPTLC is considered as the most important approach in standardization of the Ayurvedic product involving marker compound. ${ }^{17}$ In a recent study, HPLC technique has been used to estimate eugenol from different marketed Ayurvedic formulation as commercial formulations like Caturjata Churna, Lavangadi Vati, Jatiphaladi Churna, Sitopaladi Churna and clove oil. ${ }^{18}$ Recently, the researchers have developed HPTLC analytical profile of Brahmi Ghrita: A polyherbal Ayurvedic formulation. ${ }^{19}$ Therefore, fast, sensitive and accurate quality control tests for Ayurvedic formulations are desired which will be in alignment with these modern technologies. ${ }^{20}$ Keeping in view these facts, the Ayurvedic polyherbo-mineral formulation - BV was prepared using the guidelines as per AFI. The separation of the Bacoside $\mathrm{A}_{3}$ and Piperine was performed on isocratic HPLC system equipped with UV detector. Quantitative estimation of Bacoside $A_{3}$ and Piperine were performed at $345 \mathrm{~nm}$. The HPLC analysis of inhouse Brahmi vati (IBV) and three marketed samples (BV1, BV2 and BV3) suggested difference in chromatographic patterns.

\section{Materials and methods}

\subsection{Reagents}

The solvents used were of HPLC grade and were used without further purification. Water HPLC grade (Batch No. LO9A/0609/2912/ 53), Acetonitrile HPLC grade (Batch No. E10A/0210/2005/53) and Acetic acid for HPLC (Batch No. B10A/0610/0302/53) were purchased from S D Fine Chemical Limited, Mumbai. Methanol HPLC grade (Batch No.888168043) was purchased from Qualigens Fine Chemicals, Mumbai. The reference compounds, Piperine was purchased from Sigma Aldrich. Bacoside A (consisting of Bacoside $A_{3}$ and $A_{2}$ in $18 \%$ and $81 \%$ ratio respectively) was procured as a gift sample from Indian Institute of Integrative Medicine, Jammu, India.

\subsection{Preparation of Brahmi vati}

For the preparation of Brahmi vati, all minerals and metals were processed to get bhasma and pistis. Bhasmas were prepared by traditional process, involving two steps - shodhana (purification) and maran (calcinations) of gem/mineral/metals with specified plant materials. ${ }^{21}$ Akik bhasma, Abhrak bhasma, Praval bhasma and Mukta bhasma were prepared by this process. Kaharuba pisti, Manikya pisti and Sangeyasaba pisti were prepared by triturating the minerals with specified plant materials. Chandrodaya and Swarna bhasma were purchased from Ayurvedic Pharmacy, Institute of Medical Sciences, Banaras Hindu University, Varanasi. All bhasma and pistis were packed in glass bottles, labeled and stored in cool and hygienic place. Afterward, all the pulverized plant materials were sieved to find respected fine powders. For preparation of BV, powdered Chandrodaya, Saffron, Abelmoschus and Ambara were mixed together. In this, one by one bhasma and pistis were added and mixed well. In last, the powder mixture was mixed with fresh juice of $B$. monnieri and ted. Pills about $250 \mathrm{mg}$ were prepared by hand rolling, dried in shade and packed in sterilized polyethylene pouches, labeled as IBV and stored in a cool and hygienic place. ${ }^{22}$

\subsection{Marketed samples}

Three marketed samples of BV, of three different manufactures were purchased from local market and labeled as BV1, BV2 and BV3.

\subsection{HPLC system and conditions}

The HPLC system (Shimadzu Co., Japan), consisting LC-20AT pump, UV detector (Shimadzu SPD-20 A), Rheodyne 7725 I (CA, USA) manual injector with $20 \mu \mathrm{l}$ loop and phenomenex C-18(2) column $(250 \times 4.6 \mu \mathrm{m}$ ID, $5 \mu \mathrm{m})$ with a compatible guard column was used. The mobile phase consisted of Sodium acetate buffer and Acetonitrile (65:35 v/v), pH 3.2 adjusted with acetic acid The mobile phase was filtered through a $0.45 \mu \mathrm{m}$ cellulose nitrate filter membrane and was degassed prior to use.

\subsection{Sample preparation for HPLC analysis}

Dried P. longum fruits were powdered and $1 \mathrm{~g}$ of this was extracted in $250 \mathrm{ml}$ of HPLC grade methanol. The extract was 


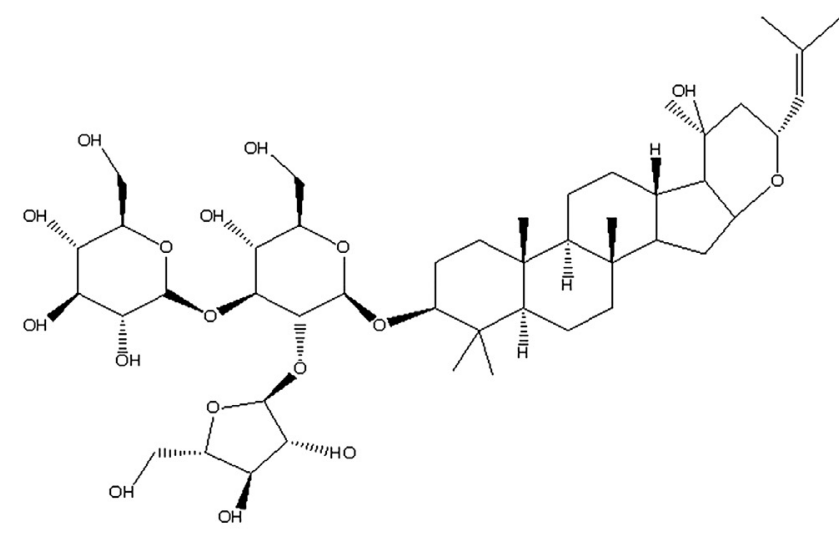

(i) Bacoside A3

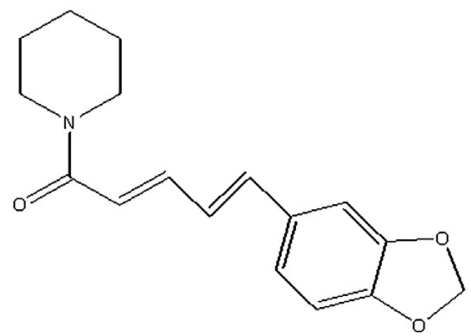

(ii) Piperine

Fig. 1. Structure (i) Bacoside $A_{3}$, (ii) Piperine.

filtered and $0.1 \mathrm{ml}$ of this was transferred to a $100 \mathrm{ml}$ volumetric flask and volume was made up to the mark. The resulting solution was used for quantification. Dried B. monnieri whole plant was powdered and $1 \mathrm{~g}$ of this was extracted in $100 \mathrm{ml}$ of HPLC grade methanol. The extract was filtered and $0.2 \mathrm{ml}$ from this was transferred to a $100 \mathrm{ml}$ volumetric flask and volume was made up to the mark. The resulting solution was used for quantification.

20 tablets $(250 \times 20=5000 \mathrm{mg}=5 \mathrm{gm})$ of each formulation including IBV, BV1, BV2 and BV3 were extracted in HPLC grade $500 \mathrm{ml}$ methanol separately. The extracts were filtered through $0.45 \mu \mathrm{m}$ filter (Millipore). $0.1 \mathrm{ml}$ from above were transferred in a $10 \mathrm{ml}$ volumetric flask and volume was made up to $10 \mathrm{ml} .20 \mu \mathrm{l}$ of the prepared samples were injected for quantification.

\subsection{Preparation of calibration curves}

To prepare standard solution of Bacoside A, $1 \mathrm{mg}$ was accurately weighed and dissolved in $100 \mathrm{ml}$ of HPLC grade methanol. Volumes of $0.1,0.2,0.3,0.4,0.5,0.6,0.7,0.8,0.9$ and $1 \mathrm{ml}$ of this solution were transferred into $10 \mathrm{ml}$ volumetric flask and volume was made up to $10 \mathrm{ml}$ with methanol. This yielded the solution of Bacoside $A$ in the concentration range $100-1000 \mathrm{ng} / \mathrm{ml}$. The Bacoside $A_{3}$ is only $18 \%$ in each dilution, thus concentration of the marker in terms of Bacoside $A_{3}$ is $18-180 \mathrm{ng} / \mathrm{ml}, 20 \mu \mathrm{l}$ of each solution were injected to injection loop and run for calibration curve of Bacoside $A_{3}$. For Piperine, $1 \mathrm{mg}$ of Piperine was accurately weighed and dissolved in $1 \mathrm{ml}$ of HPLC grade methanol. From this solution $100 \mu \mathrm{l}$ was transferred to a $100 \mathrm{ml}$ volumetric flask and volume was made up to $100 \mathrm{ml}$. Volumes of $0.2,0.4,0.6$ and $0.8 \mathrm{ml}$ of this solution were transferred into $10 \mathrm{ml}$ volumetric flask and volume was made up to $10 \mathrm{ml} .20 \mu \mathrm{l}$ of each solution were injected and run for calibration curve of Piperine.

\subsection{Method validation}

The validity of the proposed HPLC method was assessed by linearity, precision, accuracy and robustness, limit of detection (LOD) and limit of quantification (LOQ). The linearity for Bacoside $\mathrm{A}_{3}$ was $18-126 \mathrm{ng} / \mathrm{ml}$ whereas for Piperine, it was $20-80 \mathrm{ng} / \mathrm{ml}$. Precision was studied to find out intra and interday variations in the method for Bacoside $\mathrm{A}_{3}$ and Piperine two times onsame day and different day, respectively. The \% RSD was calculated which should be $<2 \%$. Intraday precision was done on the same day and interday precision was done on the different day. \% RSD was calculated for each case. Accuracy was performed by recovery study of both the marker compounds as known amount of standard component was added into preanalyzed sample and subjects them to the proposed HPLC method. The study was carried out at two different concentration levels for both the markers. Findings are presented in Table 3.

For robustness study, changes in mobile phase (from 65:35 to 63:37 and 67:33) were made and any change in retention time was measured. Limit of detection (LOD) and limit of quantification (LOQ) were verified as per the International Conference on Harmonization (ICH) guidelines. ${ }^{14}$

\section{Results and discussion}

\subsection{HPLC conditions optimization}

The aim was to develop a method for the quantitative determination of two important constituents of BV which are Bacoside and Piperine. These ingredients are common in various Ayurvedic formulations as Brahmi vati, Brahmi Rasayana and Brahmi Ghrita etc. There is no HPLC-UV method reported till date for simultaneous estimation of Bacoside $\mathrm{A}_{3}$ and Piperine. In the present work, HPLC method was developed, validated and top priority was given for complete separation of Bacoside $A_{3}$ and Piperine from Brahmi vati (BV).

The mobile phase was chosen after several trials, which consisted of Sodium acetate buffer and Acetonitrile (65:35 v/v), pH 3.2 adjusted with acetic acid was finally selected in order to achieve optimum separation, high sensitivity and good peak shape. The detection wavelength was chosen at $345 \mathrm{~nm}$ since Bacoside $\mathrm{A}_{3}$ and Piperine have better absorption and sensitivity at this wavelength.

In the present study, a shorter run time ( $30 \mathrm{~min}$ ) and complete separation of Bacoside $A_{3}$ and Piperine was achieved. The retention time for Bacoside $A_{3}$ and Piperine were found to be $6.83 \mathrm{~min}$ and 9.52 min respectively. The chromatogram also showed several other unidentified peaks. The peaks in the chromatogram of formulations were identified by comparison of the retention time with those corresponding to the marker compounds. Fig. 2 represents characteristic chromatogram of standard Bacoside $A_{3}$ and Piperine and Fig. 3 represents peaks of Bacoside $A_{3}$ and Piperine in Brahmi vati formulation (IBV).

\subsection{Calibration and method validation}

The HPLC method was validated by defining the linearity, limit of detection (LOD), limit of quantification (LOQ), precision, accuracy 


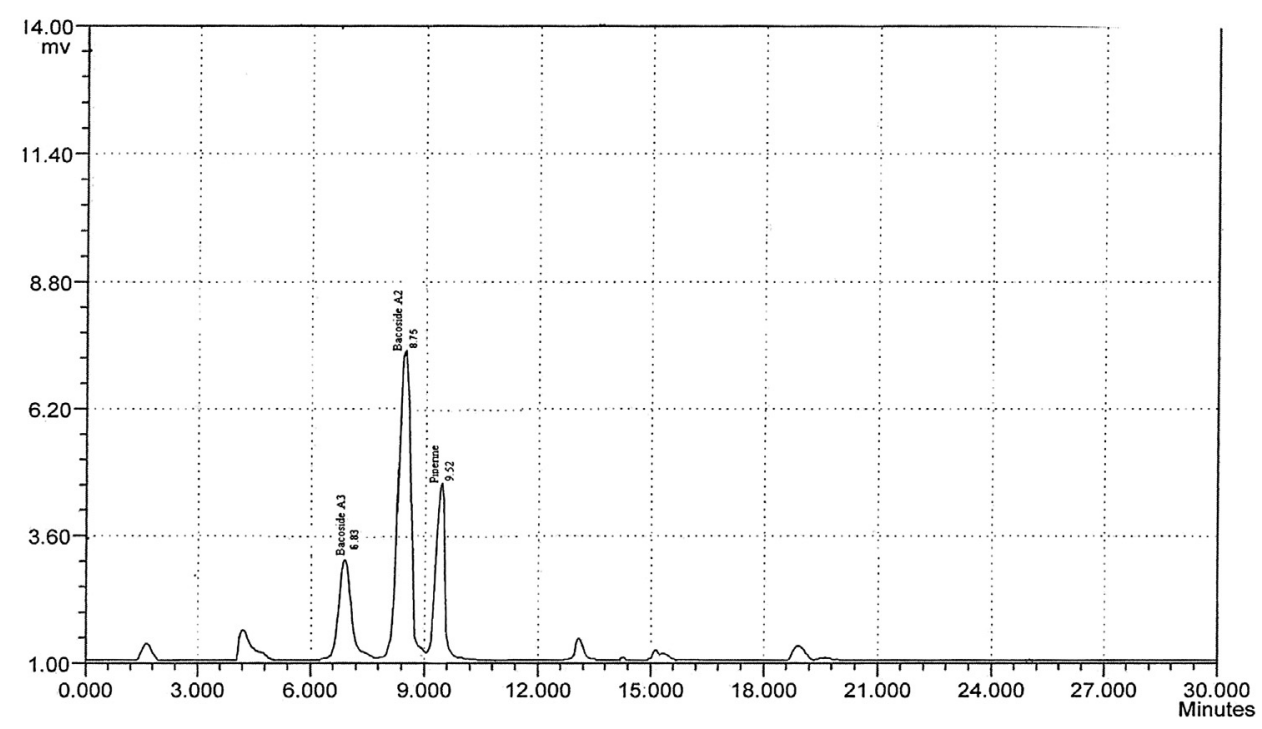

Fig. 2. Chromatogram representing peaks of Bacoside $A_{3}$ and Piperine as marker compound.

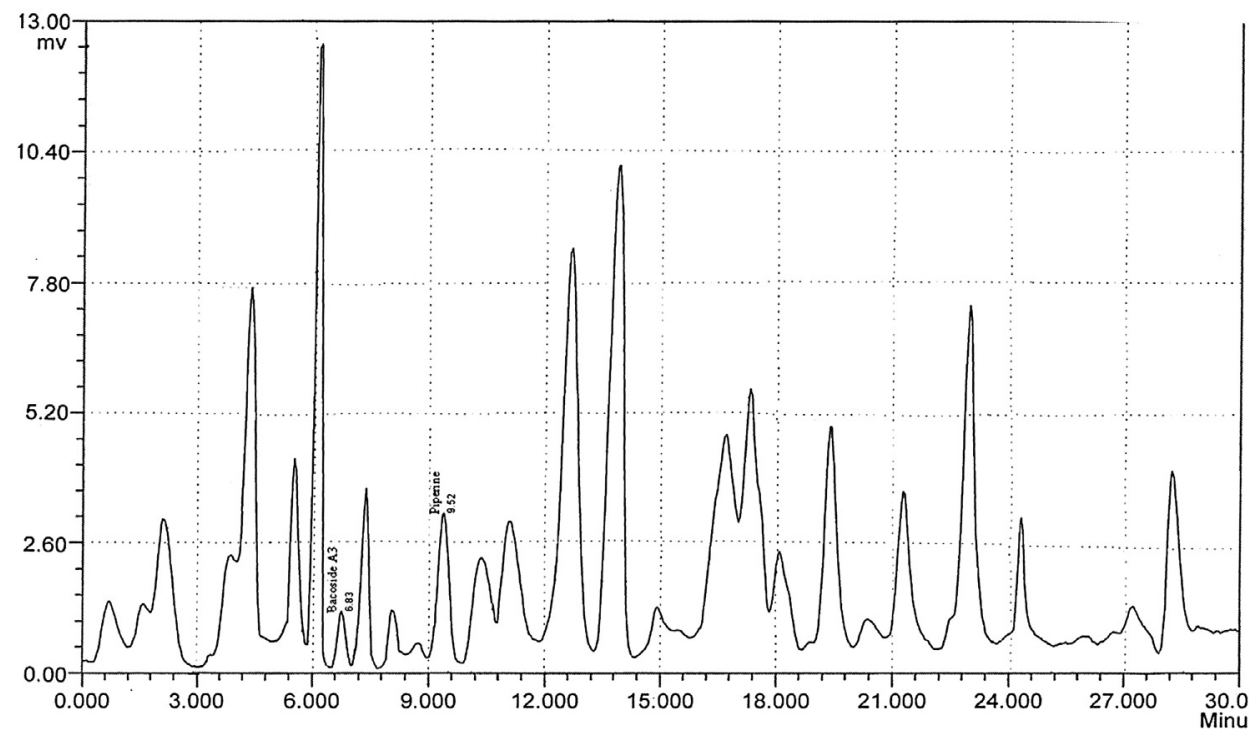

Fig. 3. Chromatogram representing peaks of Bacoside $A_{3}$ and Piperine in Brahmi vati formulation (IBV).

and robustness. The method was evaluated by determining the precision in the retention time of both markers in a standard sample as well as in the marketed formulations and a low RSD value (0.55\% and $0.29 \%$ ) indicated high precision of the method. It was observed that the other constituents present in the formulation did not interfere with any of the markers indicating specificity of the method.

A linear relationship between peak areas and concentrations was observed over given range for both compounds (Table 2). Standard solutions of Bacoside $A\left(A_{3}\right.$ and $A_{2}$ in $18 \%$ and $81 \%$ ratio respectively) in the range of $100-1000 \mathrm{ng} / \mathrm{ml}$ were prepared which consists of $18-180 \mathrm{ng} / \mathrm{ml}$ Bacoside $\mathrm{A}_{3}$ and of Piperine in the range of $10-100 \mathrm{ng} / \mathrm{ml}$ were prepared and analyzed. The regression equations of these curves are shown in Table 2 and their coefficients of regression $\left(R^{2}\right)$ were 0.998 confirming the linearity of the method. A signal three times higher than noise was regarded as the detection limit. The LOD value for Bacoside $A_{3}$ and Piperine were found to be $4 \mathrm{ng} / \mathrm{ml}$ and $5 \mathrm{ng} / \mathrm{ml}$ and LOQ value were found to be $13.2 \mathrm{ng} / \mathrm{ml}$ and $16.5 \mathrm{ng} / \mathrm{ml}$ respectively.

The intra and interday precisions (expressed as RSD) and accuracy (expressed as recovery) for the two analytes were determined by spiked samples with the standard solutions $(n=6)$,

Table 2

Linearity, LOD, LOQ, regression curves of the HPLC method.

\begin{tabular}{|c|c|c|c|c|c|c|}
\hline Parameter/Marker & $\begin{array}{l}\text { Linearity } \mathrm{R} \\
\text { range (ng/ml) }\end{array}$ & $\begin{array}{l}\text { LOD } \\
(\mathrm{ng} / \mathrm{ml})\end{array}$ & $\begin{array}{l}\text { LOQ } \\
(\mathrm{ng} / \mathrm{ml})\end{array}$ & Calibration curve & $R^{2}$ & $\operatorname{tR}(\min )$ \\
\hline Bacoside $A_{3}$ & $18-180$ & 4 & 13.2 & $Y=572.5 X+326.5$ & 0.998 & $6.83 \pm 0.015$ \\
\hline Piperine & $20-80$ & 5 & 16.5 & $Y=110.1 X-61.96$ & 0.998 & $9.52 \pm 0.011$ \\
\hline
\end{tabular}


Table 3

Intraday and interday precision and accuracy.

\begin{tabular}{|c|c|c|c|c|}
\hline \multirow[t]{2}{*}{ Marker } & \multicolumn{2}{|l|}{ Intraday } & \multicolumn{2}{|l|}{ Interday } \\
\hline & Mean $\pm \mathrm{SD}(\mathrm{ng} / \mathrm{ml})$ & RSD (\%) & Mean $\pm \mathrm{SD}(\mathrm{ng} / \mathrm{ml})$ & RSD (\%) \\
\hline Bacoside $\mathrm{A}_{3}$ & $71.5 \pm 1.049$ & 1.46 & $71 \pm 0.894$ & 1.25 \\
\hline Piperine & $37.83 \pm 0.752$ & 1.98 & $38.33 \pm 0.516$ & 1.34 \\
\hline
\end{tabular}

consecutively, using the analytical method described above. The coefficient variations of intra and interday studies were both less than 2.0\%. The results of the recovery of Bacoside $A_{3}$ and Piperine ranged between 98.0 and $101.66 \%$. The precision as well as the reproducibility of this method was satisfactory (Tables 3 and 4). The robustness of the method was investigated under changed conditions which include changes of mobile phase composition. Changes in mobile phase (from 65:35 to 63:37 and 67:33) showed robustness of the method as insignificant change in retention time was observed and \% RSD was less than 2 in each case (Table 5). The degree of reproducibility of the results obtained as a result of small deliberate variations in the mobile phase composition has proven that the method is robust.

The in-house and marketed samples of BV were analyzed by the present method.

\subsection{RP-HPLC analysis and quantitation of markers in in-house and marketed samples of Brahmi vati}

RP-HPLC analysis of the prepared formulation showed the presence of many peaks due to the presence of several ingredients in BV. Two markers, Bacoside $\mathrm{A}_{3}$ and Piperine were identified and separated in this formulation. The amounts of these marker constituents present per $\mathrm{g}$ of the formulation are given in Table 6 .

Chromatogram of in-house preparation showed a large number of peaks and differs markedly from marketed samples in number as well as peak area. The larger number of peaks in in-house preparation is may be due to the presence of several ingredients in this formulation. Use of exhausted material, wrong material, storage conditions, different altitude and area of drug collection and adoption of different manufacturing processes are the expected regions behind the difference in chromatograms of in-house and marketed samples of the same formulation.

The Bacoside $A$ (Bacoside $A_{3}$ and $A_{2}$ ) is a saponin from B. monnieri and reported to have antiepileptic, anticancer, hepatoprotective, memory enhancing and antidepressant activities. ${ }^{23-}$ ${ }^{27}$ Piperine, an alkaloid found in P. longum L. reported to have antidepressant, antioxidant, anti-inflammatory, antihypertensive, antitumor, hepatoprotective and anti-asthmatic properties. ${ }^{28}$ Presence of adequate amount of these two marker compounds in BV establishes its identity and ensures the quality and efficacy of the formulation. In the result of quantitative analysis, $B$. monnieri showed the presence of $0.273 \%$ of Bacoside $\mathrm{A}_{3}$ and $P$. longum (PL) showed the presence of $1.487 \%$ of Piperine (Table 6).

The BV formulation of $250 \mathrm{mg}$ contains $18 \mathrm{mg}$ of BM and $6 \mathrm{mg}$ of PL. So by this data the expected amount of Bacoside $A_{3}$ and Piperine must be $196.56 \mu \mathrm{g}$ and $356.88 \mu \mathrm{g}$ per $\mathrm{g}$ of $\mathrm{BV}$. The result of

Table 4

Recovery studies of Bacoside $\mathrm{A}_{3}$ and Piperine.

\begin{tabular}{llllc}
\hline Marker & $\begin{array}{l}\text { Basal } \\
\text { amount (ng) }\end{array}$ & $\begin{array}{l}\text { Amount } \\
\text { added (ng) }\end{array}$ & $\begin{array}{l}\text { Amount } \\
\text { recovered (ng) }\end{array}$ & $\begin{array}{l}\text { \% Mean } \\
\text { recovery }\end{array}$ \\
\hline Bacoside $A_{3}$ & 72 & 72 & 142.99 & 98.61 \\
Piperine & 72 & 90 & 160.99 & 98.88 \\
& 50 & 50 & 99.00 & 98.00 \\
& 50 & 60 & 110.97 & 101.66 \\
\hline
\end{tabular}

Table 5

Robustness of the method by changing the composition of the mobile phase of Bacoside $\mathrm{A}_{3}$ (54 ng/ml) and Piperine (40 ng/ml).

\begin{tabular}{|c|c|c|c|c|c|c|}
\hline \multirow{2}{*}{\multicolumn{3}{|c|}{$\frac{\text { Mobile phase composition }}{\text { Sodium acetate buffer:Acetonitrile }}$}} & \multicolumn{2}{|l|}{ Bacoside $\mathrm{A}_{3}$} & \multicolumn{2}{|l|}{ Piperine } \\
\hline & & & \multirow{2}{*}{$\begin{array}{l}\text { Mean } t R \pm \\
\text { SD }\end{array}$} & \multirow[t]{2}{*}{$\%$ RSD } & \multirow{2}{*}{$\begin{array}{l}\text { Mean } \mathrm{tR} \pm \\
\mathrm{SD}\end{array}$} & \multirow[t]{2}{*}{ \% RSD } \\
\hline Original & Used & Levels & & & & \\
\hline \multirow{3}{*}{$65: 35$} & $63: 37$ & -2 & $6.84 \pm 0.08$ & 1.28 & $9.52 \pm 0.13$ & 1.41 \\
\hline & 65:35 & 0 & $6.83 \pm 0.03$ & 0.43 & $9.52 \pm 0.02$ & 0.27 \\
\hline & $67: 33$ & +2 & $6.81 \pm 0.09$ & 1.34 & $9.53 \pm 0.14$ & 1.53 \\
\hline
\end{tabular}

Table 6

Quantification of Bacoside $A_{3}$ and Piperine in the in-house and marketed formulations of Brahmi vati

\begin{tabular}{lcr}
\hline & $\begin{array}{l}\text { Bacoside } \mathrm{A}_{3} \text { Mean }(\mu \mathrm{g} / \mathrm{gm}) \\
\pm \mathrm{S} . \mathrm{D}, n=6\end{array}$ & $\begin{array}{l}\text { Piperine Mean }(\mu \mathrm{g} / \\
\mathrm{gm}) \\
\pm \mathrm{S} . \mathrm{D}, n=6\end{array}$ \\
\hline BM & $2733 \pm 32.890$ & - \\
PL & - & $14,870 \pm 64.443$ \\
IBV & $192 \pm 3.742$ & $343 \pm 17.527$ \\
BV1 & $188 \pm 4.336$ & $340.5 \pm 13.065$ \\
BV2 & $95.33 \pm 3.559$ & $152.16 \pm 13.288$ \\
BV3 & $71.66 \pm 4.320$ & $126 \pm 11.662$ \\
\hline
\end{tabular}

BM: B. monnieri, PL: P. longum, IBV: In-house standard preparation, BV1-BV3: Marketed samples.

quantitative analysis revealed that IBV and BV1 formulations have Bacoside $A_{3}$ and Piperine in 5\% range of the expected value while, BV2 and BV3 have less than $-5 \%$ values of the expected amount. The present study revealed that the marketed samples have lack of uniformity in Bacoside $A_{3}$ and Piperine content. There are different variety of Brahmi and Piper plants available having a different percent yield of Bacoside A and Piperine respectively. Use of plant materials having a low percent yield of secondary metabolites may result in a low quality formulation. Another reason responsible for lack of uniformity, may be the unsuitable storage condition, of raw materials and the finished products which can reduce the active constituents of the formulation.

\section{Conclusion}

The results obtained indicate that there is a lack of uniformity in the amount of marker compounds present in the same formulation marketed by different manufactures. So there should be a set of standards for every traditional formulation. The developed method is fast, precise and accurate and may be useful for evaluation of quality of BV in future.

\section{Conflicts of interest}

All authors have none to declare.

\section{Acknowledgment}

The authors are thankful to the Director of Indian Institute of Integrative Medicine, Jammu, India for providing gift sample of standard compounds.

\section{References}

1. Gold FL, Lewin N, Flomenbaum N, Hawland MA. The pernicious panacea: herbal medicine. Hosp Physician. 1982;18:64-87.

2. Vulto AG, Smet PAGM. Drug used in non-orthodox medicine. In: Meyler's Side Effects of Drugs. 11th ed. Amsterdam: Elsevier; 1988:99-105.

3. Ayurvedic Formulary of India - Part-I. 2nd ed. New Delhi: Government of India, Ministry of Health and Family Planning, Department of Health; 2003. 
4. Ayurvedic Formulary of India - Part-II. 2nd ed. New Delhi: Government of India, Ministry of Health and Family Planning, Department of Health; 2003.

5. Singh HK, Dhawan BN. Effect of B. monnieri Linn. (Brahmi) extract on avoidance responses in rats. J Ethnopharmacol. 1982;5:205-214.

6. Joshi H, Parle M. Management of dementia through ayurvedic formulation brahmi rasayana BR-2T in mice. Alzheimer's Dementia. 2005;1:S64-S69.

7. Nathan PJ, Clarke J, Lloyd J. The acute effects of an extract of Bacopa monnieri (Brahmi) on cognitive function in healthy normal subjects. Hum Psychopharmacol. 2001;16:345-351.

8. Saraf MK, Prabhakar S, Khanduja KL, Anand A. Bacopa monniera attenuates scopolamine-induced impairment of spatial memory in mice. Evid Based Complement Alternat Med. 2011;2011:236186.

9. Singh HK, Dhawan BN. Neuropsychopharmacological effects of the Ayurvedic nootropic Bacopa monnieri Linn. (Brahmi). Indian J Pharmacol. 1997;29:359-365.

10. Murthy PBS, Raju VR, Ramakrisana T, et al. Estimation of twelve bacopa saponins in Bacopa monnieri extracts and formulations by high-performance liquid chromatography. Chem Pharm Bull. 2006;54:907-911.

11. Singh N, Kumar S, Singh P, Raj HG, Prasad AK, Parmar VS. Piper longum Linn. extract inhibits TNF-alpha-induced expression of cell adhesion molecules by inhibiting NF-kappaB activation and microsomal lipid peroxidation. Phytomedicine. 2008;15:284-291.

12. Rastogi S, Pal R, Kulshreshtha DK. Bacoside $A_{3}-$ a triterpenoid saponin from Bacopa monnieri. Phytochemistry. 1994:36:133-137.

13. Chonpathompikunlert P, Wattanathorn J, Muchimapura S. Piperine, the main alkaloid of Thai black pepper, protects against neurodegeneration and cognitive impairment in animal model of cognitive deficit like condition of Alzheimer's disease. Food Chem Toxicol. 2010;48:798-802.

14. Stability Testing of New Drug Substances and Products Q1 A (R2). Geneva: International Conference on Harmonization, IFPMA; 2003.

15. Giang DT, Hoang VD. Comparative study of RP-HPLC and UV spectrophotometric techniques for the simultaneous determination of amoxicillin and cloxacillin in capsules. J Young Pharm. 2010;2:190-195.

16. Thiruvengada RV, Mohamed STs, Ramkanth S, Alagusundaram M, Ganaprakash K, Madhusudhana CC. A simple RP-HPLC method for quantitation of itopride $\mathrm{HCl}$ in tablet dosage form. J Young Pharm. 2010;2:410-413.
17. Nagalekshmi R, Menon A, Chandrasekharan DK, Nair CK. Hepatoprotective activity of Andrographis paniculata and Swertia chirayita. Food Chem Toxicol 2011;49:3367-3373.

18. Saran S, Menon SK, Shailajan S, Pokharna P. Validated RP-HPLC method to estimate eugenol from commercial formulations like Caturjata Churna, Lavangadi Vati, Jatiphaladi Churna, Sitopaladi Churna and clove oil. J Pharm Res. 2013;6:53-60.

19. Gubbannavar JS, Chandola H, Harisha CR, Kalyani R, Shukla VJ. Analytica profile of Brahmi Ghrita: a polyherbal Ayurvedic formulation. Ayu. 2012;33: 289-293.

20. Chitlange SS, Kulkarni PS, Patil D, Patwardhan B, Nanda RK. High-performance liquid chromatographic fingerprint for quality control of Terminalia arjuna containing Ayurvedic churna formulation. J AOAC Int. 2009;92:1016-1020.

21. Prakash B. Use of metals in Ayurvedic medicines. Indian J Hist Sci. 1997;32: $1-28$.

22. Mishra A, Mishra AK, Ghosh AK, Jha S. Standardization of a traditional polyherbo-mineral formulation Brahmi vati. Afr I Tradit Complementary Altern Med. 2013;10:390-396.

23. Mathew J, Paul J, Nandhu MS, Paulose CS. Bacopa monnieri and Bacoside-A for ameliorating epilepsy associated behavioral deficits. Fitoterapia. 2010; $81: 315-322$.

24. Prakash NS, Sundaram R, Mitra SK. In vitro and in vivo anticancer activity of Bacoside A from whole plant of Bacopa monnieri (Linn). Am J Pharmacol Toxicol. 2011;6:11-19.

25. Janani P, Sivakumari K, Parthasarathy C. Hepatoprotective activity of bacoside A against $\mathrm{N}$-nitrosodiethylamine-induced liver toxicity in adult rats. Cell Biol Toxicol. 2009;25:425-434.

26. Singh HK, Rastogi RP, Srimal RC, Dhawan BN. Effect of bacoside A and B in avoidance responses in rat. Phytother Res. 1988;2:70-75.

27. Calabrese C, Gregory WL, Leo M, Kraemer D, Bone K, Oken B. Effect of a standardized Bacopa monnieri extract on cognitive performance, anxiety and depression in the elderly: a randomized, double blind, placebo controlled trail. J Altern Complement Med. 2008;14:707-713.

28. Singh A, Duggal S. Piperine - a review of advances in pharmacology. Inter J Pharm Sci Nanotechnol. 2009;2:3-6. 